\title{
$\alpha$ 鉄中の水素拡散におよぼす置換型合金元素の影響
}

\author{
羽木 秀樹* 林 安 德* 大谷南海男*
}

J. Japan Inst. Metals, Vol, 45, No.3(1981),pp.276 282

Effect of Substitutional Alloying Elements on the Diffusion Coefficient

of Hydrogen in $\alpha$-Iron

Hideki Hagi*, Yasunori Hayashi* and Namio Ohtani*

Diffusion of hydrogen has been studied in iron alloys with substitutional elements which act as trapping sites. With the assumption of local equilibrium for hydrogen distribution and the thermal averaging for the jump rate of the hydrogen atom, the apparent diffusion coefficient of hydrogen is derived by considering the interaction energy $E_{\mathrm{B} 1}$ between a dissolved hydrogen atom and a substitutional alloying element, and the change $\Delta E$ in the energy of the saddle point between the trapping site and the neighboring lattice site.

Diffusion coefficients of hydrogen in annealed poly-crystalline specimens of $\mathrm{Fe}-(0.50 \sim$ 3.81 at $\%) \mathrm{Ni}, \mathrm{Fe}-(0.39 \sim 4.67 \mathrm{at} \%) \mathrm{Cr}$, and $\mathrm{Fe}-(0.59 \sim 4.63 \mathrm{at} \%) \mathrm{Co}$ alloys have been measured by the electrochemical permeation method in which alcoholic solutions have been used as electrolytes at temperatures between 230 and $300 \mathrm{~K}$. The experimental permeation curves were analyzed by considering the variation of the hydrogen concentration beneath the cathodic surface during the measurements. The observed temperature dependence of diffusion coefficient of hydrogen can be explained using the following values; $\Delta E \simeq 0, E_{\mathrm{B} 1} \simeq 8.4 \mathrm{~kJ} / \mathrm{mol}$ for $\mathrm{Fe}-\mathrm{Cr}$ alloys and $\Delta E \simeq 4.2 \mathrm{~kJ} / \mathrm{mol}, E_{\mathrm{B} 1} \simeq 7.6 \mathrm{~kJ} / \mathrm{mol}$ for $\mathrm{Fe}-\mathrm{Ni}$ and $\mathrm{Fe}-\mathrm{Co}$ alloys.

(Received August 14, 1980)

\section{I. 緒㝘}

鉄鋼材料の水素による遅れ破壞はよく知られているが， その破壊機構の解明はまだ十分とは言えない，したがって 鋼中の水素の抬散係数を正確に求めることは，遮れ破壊機 構を解明するために重要である。これまでの多くの報告(1) によると, $500 \mathrm{~K}$ 以上の高温に和ける水素の执散係数とし てはほぼ一致した値が得られているにもかかわらず，500 K以下の低温，とくに室温付近に和りる抎散係数は研究者 によって著しく異なって特り，高温から外挿される值より 小さい。この低温に和ける異常性は転位 ${ }^{(2)(3)}$, 粒界 ${ }^{(4)(5)}$, ボイド(6)〜(11)などの格子久陷や，不純物(合金元素) (12)〜(19) による水素のトラップ效果 ${ }^{(8)(20) \sim(24)}$ に基づくものと考壳 られている。

水素ぜい性が顕著に現われるのは高張力鋼，ニッケル鋼 などの合金鋼であるので，止素の桩散におよぼす合金元素 の影響を検討することは極めて重要である。したがって $\mathrm{Ni}^{(13)(16)(18)}, \mathrm{Cr}^{(13)(15)(19)}, \mathrm{Si} i^{(12)(13)}$ などの影響が調ベられ てはいるが，いずれも室温以上での結果であって，しかも $\alpha$ 相に拈けるデータは少ないし，ばらつきも大きい，水素 の抁散係数に対するトラップの影響は低温になるほど大き
いので，置換型固溶原子によるトラップ效果を詳細に議論

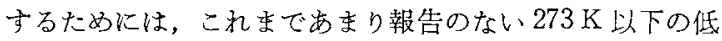
温での水素の拡散係数を調べることが効果的である。

室温付近に和ける水素の拡散係数の湘定法としてょく用

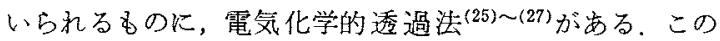
カ法では，カソード側から電気化学的に導入された水菜が 試料内部を透過して，アノード側でイオン化する。この水 素の透過速度をアノード電流として測定する。この澌定法 は実験装置が簡単で，ガス透過法に比べて $10^{4}$ 倍注ど感度 が大きい(3)。しかし，これまでの実験では電解液に主とし て水溶液が用いられていたために，実験温度が 273〜373 K の範囲に限られていた(1)。

本研究では鉄中の水素の拡散に就よ゙す種々の合金元素 の影響を知るために，電解液にアルコール溶液を用いた電 気化学的透過法 ${ }^{(28)(29)}$ を用いて，230〜300 Kにおける種々 の鉄合金中の水素の拡散係数を求めた，合金元素として は，水素ぜい性がとくに問題となる高張力鋼などの特殊鋼 に合金元素として用いられて， $\alpha$ 鉄の固溶体領域が疝い2 元合金を形成する $\mathrm{Ni}, \mathrm{Cr}, \mathrm{Co}$ 選んだ。さらに水素の㹡 散係数に対する置換型合金元素の影響をトラップモデルを 用いて定式化して実験結果を考察した。 
II. 実 験 万 法

\section{1. 試料}

試料としては市肘の電解鉄と高純度の $\mathrm{Ni}, \mathrm{Cr}, \mathrm{Co}$ を真 空溶解して作成した $\mathrm{Fe}-(0.50 \sim 3.81$ at \%) Ni, Fe- $(0.39$ $\sim 4.67 \mathrm{at} \%) \mathrm{Cr}, \mathrm{Fe}-(0.59 \sim 4.63 \mathrm{at} \%) \mathrm{Co}$ 考用いた，平衡 状態㘠(30)でみる限りでは，これらの合金はすべて $\alpha$ 相領 域炏る。これを厚さ $1 \mathrm{~mm}$ 程度に压延した後 $20 \mathrm{~mm} \times$ $25 \mathrm{~mm}$ に切断して，表面をエメリ一研摩した。これを 973 $\mathrm{K}$ で $28.8 \mathrm{ks}(8 \mathrm{~h})$ 真空焼釷した後, 化学研摩して,アノ一 ド側に Pdメッキを施した。

\section{2. 透過曲線の測定}

水素の透過曲線は電気化学的方法によって求めた，すな わら試料のカソード側でカソード電流密度を一定にして， カソード反応によって表面に発生した水素を試料内部に導 入する。アノード表面の電極電位を適当な值に保持するこ とによって,アノード側へ透過してきた水素原子を㜊滞なく イオン化させて，この反応速度をつノード電流として測定 した. $273 \mathrm{~K}$ 以下での測定を容易にするために，カソード 電解液としては $0.5 \mathrm{kmol} / \mathrm{m}^{3} \mathrm{H}_{2} \mathrm{SO}_{4}+5 \mathrm{~g} / \mathrm{m}^{3} \mathrm{As}_{2} \mathrm{O}_{3}$ 水溶 液とエチルアルコールとを等量ずつ混合したものを用い， アノード電解液としては $0.2 \mathrm{kmol} / \mathrm{m}^{3} \mathrm{KOH}$ を含むエチ ルアルコール溶液に少量の水を加えたものを用いた。

\section{3. 透過曲線の解析法}

実測される水素の透過曲線から拻散係数を求めるに当っ ては，カッード表面随下の水素濃度が時間とともに变化す ることを考虑した，その解析法は前報 ${ }^{(29)}$ に示したが，概 略は次のと叔りである。

拡散が Fick の法則飞従い，カソード表面直下の水素濃 度が分極と同時に一定值 $C_{\mathrm{s}}$ となり，アノード表面直下の 水素濃度は常汇零に保たれる場合には，水素の透過速度， $J(t)$ ，は次式で表わされる。

$$
J(t)=\frac{D C_{\mathrm{s}}}{L}\left\{1+2 \sum_{n=1}^{\infty} \exp \left(-\frac{D n^{2} \pi^{2} t}{L^{2}}\right)\right\}
$$

ここで $D$ は水素の拡散係数，Lは板厚である.

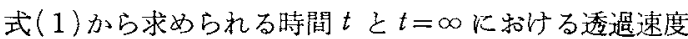
の比 $J(t) / J(\infty)$ と規格化時間 $\tau\left(=D t / L^{2}\right)$ との関保を用い $\tau$ ，実測透過曲線， $i_{\mathrm{a}}(t)$ ，を整理する，すなわ台実測透過 曲線恃定常透過速度 $i_{\mathrm{a}}(\infty)$ 西るい性透過速度の極大值 $i_{\mathrm{a}}{ }^{*}$

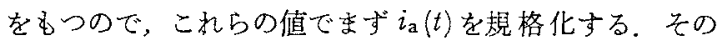
後この規格化された透過速度の此 $i_{\mathrm{a}}(t) / i_{\mathrm{a}}(\infty)$ あるいは

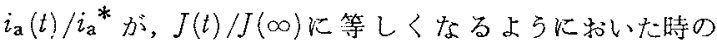
こと実測される $t$ との関係をプロットする。このことしの 関係を示す曲線湟点で接線をひき，その傾き $\left(D / L^{2}\right)$ か 号拡散保数 $D$ を得る。

\section{III. 実 験 結 果}

電解銠の場合 ${ }^{(29)}$ と同じょうに, 試料の鉄合金中の水素

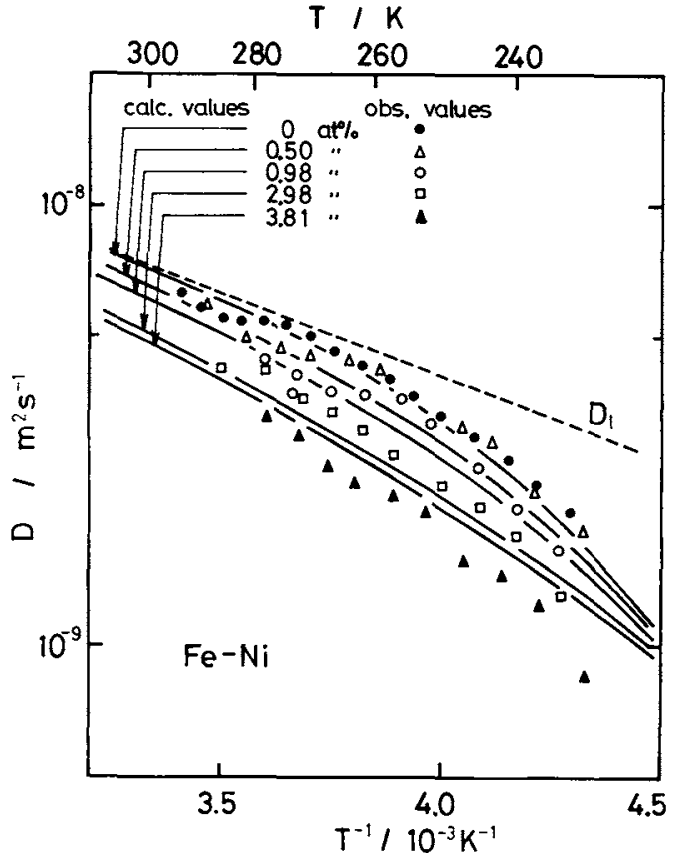

Fig.1 Arrhenius plot of the diffusion coefficient of hydrogen observed for $\mathrm{Fe}-\mathrm{Ni}$ alloys and calculated from eq. (10) where $\Delta E=4.2 \mathrm{~kJ} / \mathrm{mol}$ and $E_{\mathrm{B} 1}$ $=7.6 \mathrm{~kJ} / \mathrm{mol} . D_{1}$; the diffusion coefficient of hydrogen in normal lattice sites of iron.

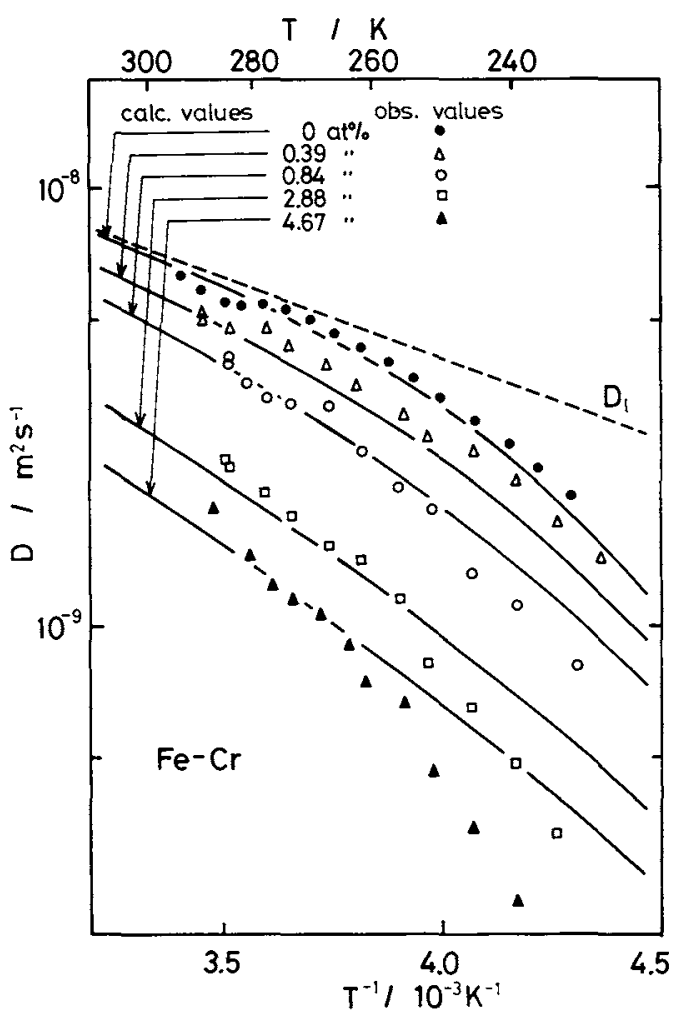

Fig.2 Arrhenius plot of the diffusion coefficient of hydrogen observed for $\mathrm{Fe}-\mathrm{Cr}$ alloys and calculated from eq. (10) where $\Delta E=0$ and $E_{\mathrm{B} 1}=8.4$ $\mathrm{kJ} / \mathrm{mol}$. 


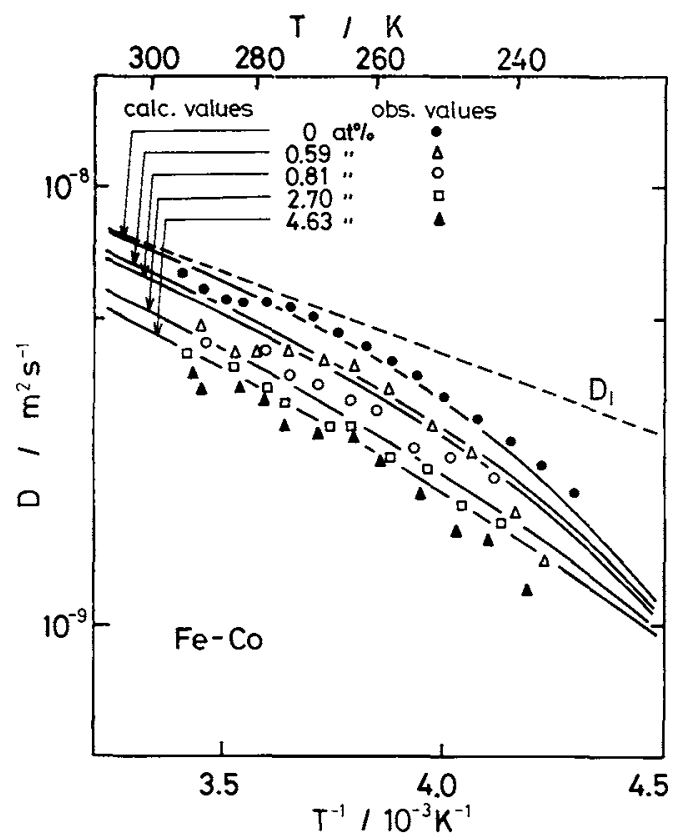

Fig.3 Arrhenius plot of the diffusion coefficient of hydrogen observed for $\mathrm{Fe}-\mathrm{Co}$ alloys and calculated from eq. (10) where $\Delta E=4.2 \mathrm{~kJ} / \mathrm{mol}$ and $E_{\mathrm{B} 1}=7.6 \mathrm{~kJ} / \mathrm{mol}$.

の透過曲線の形はカンード電流密度 $\left(i_{c}\right)$ によって変化し た。 $i_{c}$ が小さい場合には定常透過速度に達するまでに長時 間を要するが，活が大きい場合には透過速度に極大值が現 われた。このような透過朋線から拡散係数を決定するため に, 透過将線の $i_{\mathrm{c}}$ 依存性を求めて, 前述のようにして と $t$ の関係でプロットしな和した。そしてこの曲線が $\tau=0 \sim 0.1$ の篰团で原点を通る直線となるような $i_{\mathrm{c}}$ の值 を求めた。この条件を満たす $i_{\mathrm{c}}$ 值の範囲は試料の合金量 によって変化するが，前報 ${ }^{(29)} て ゙$ 示したように，この方法 を用いれば $i_{\mathrm{c}}$ や試料の板厚に依存しない水素の拡散係数 を決定でさる。

このよらにして設定した $i_{\mathrm{c}}$ 值に和ける水素の透過曲線 を解析して，鉄合金中での水素の抎散係数を得た. Fig.1， 2,3 はそれぞれ Fe-Ni，Fe-Cr，Fe-Co 合金中の亦素の挔 散係数を示す。な脑図中には多結晶の電解鉄に和いて測定

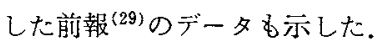

\section{IV. 考察}

\section{1. トラップモデル}

鉄中の水素払散に叔けるトラップ效果は，いるいるなポ テンシャルモデルと理論によって議論されている(9)(10)(31) 〜 (37). ところが転位やボイドをトラップとして取り技った あのが多くて，不純物元素(とく㯰換型合全元溸)による トラップ現象を定式化したものとしては，例党ば Koiwa の報告 ${ }^{(37)}$ があるが，その数は多くない，また非線型抬散 万程式を用いてトラップ効果を解析すると, 一般に数学的
表現が複雑になるために，その理論を実験結果と比較する ことが困難な場合が多い。

そこで本研究では，極めて近似的ではあるがトラップ位 置の水素と格子間位置の水素との間に平衡が成り立つと仮 定して，Fe-X 2 元合金中の水素の拡散係数を定式化する. 水素の安定位置を8面訛位置とすれば，蹸接する安定位置 の間の中間位置(ポテンシャルの鞍点)は 4 面体位置とな る，仮定として(i) 㯰換型合金元素Xを添加すると，最隣 接 8 面体位置と最䇟接 4 面体位置の水素のポテンシャルの みが変化する。(ii) 合金量は極めて少ないるのする。こ 場合の Fe-X 2 元合金中の水素のポテンシャル(37)は Fig. 4 のよ5に表わされる。図中の $Q$ は合金元素の影響を受け ていない格子中の乐素の应散の活性化エネルギー， $E_{\mathrm{B} 1}$ は 合金元素と水素の相互作用エネルギー， $\Delta E$ は合金元素を 添加したことによる 4 面体位置のポテンシャルエネルギー の減少玉たは增加分で，ポテンシャルエネルギーが減少す る場合を $\Delta E>0$ とする。ここでは $E_{\mathrm{B} 1}$ の相互作用エネル ギーをもつ8面体位置を合金トラップ位狊と呼ぶことにす 万.

水素の分有が熱平衡分布に従う女仮定し，

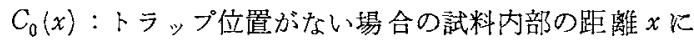
和ける水素濃度

$C_{\mathrm{t}}(x)$ : 試料内部の距離 $x$ に存在するトラップ位置での 水素濃度

とすれば， $\mathrm{C}_{\mathrm{t}}(x)$ は次式で表わされる。

$$
C_{\mathrm{t}}(x)=C_{0}(x) \exp \left(E_{\mathrm{B} 1} / R T\right)
$$

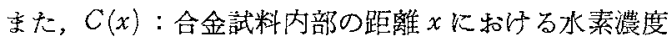

$K_{1}: 8$ 面体位䈯の総数に対する合金トラップ 位惪の数の割合

とすれば，合金試料中の水素の濃度， $C(x)$ ， は $C_{0}(x)$ と $C_{\mathrm{t}}(x)$ の平均として次式で表わされる。

$$
\begin{aligned}
C(x) & =\left(1-K_{1}\right) C_{0}(x)+K_{1} C_{t}(x) \\
& =C_{0}(x)\left\{1-K_{1}+K_{1} \exp \left(E_{\mathrm{B}_{1}} / R T\right)\right\}
\end{aligned}
$$

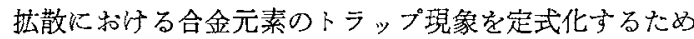
には，隣接する8 面体位䈆の間の水素の移行速度を考觉な くてはならない.8面体位置に和ける水素の濃度が熱平衡 の条件で与えられると仮定し，すべての水素の隣接 8 面体 位置への移行速度を平均持ることによって，合金中の水素

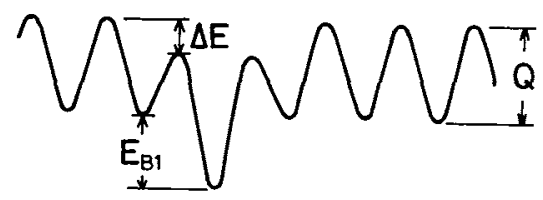

Fig.4 A model for trapping sites : $\Delta E$; the change in the energy of the saddle point between the trapping site and the neighboring lattice sites, $E_{\mathrm{B} 1}$; the interaction energy between a dissolved hydrogen atom and a substitutional alloying element, $Q$; the activation energy for diffusion of hydrogen in normal lattice sites of iron. 
の払散係数を理論的に導出した Krivoglatz(38) え方のもとに，㧓散係数に扔上ぼす合金元素の影響を定式 化した：

Fig.4k示したポテンシャルのもとでは，1つの8面体 位置から隣の8 面体位置への桩散経路としては，Fig.5 K 示すよらに(i)，(ii)，(iii)の3通りが考えられる。したがっ て，この上うに拡散経路を分類したときの 8 面体位置を， Fig.5に示すように $\mathrm{A}_{i}(i=1,2,3), \mathrm{B}_{i}(i=1,2,3)$ とす る。前述の合金トラップ位置の密度 $K_{1}$ を考虑すれば， $A_{i}$ を舍をA面上に合金トラップ位置が存在する確率，すなわ ち(i)の拡散経路が存在する確率は $K_{1}$ である。また(ii) と (iii) の掋散経路が存在する確率はそれぞれ $K_{1},\left(1-2 K_{1}\right)$ で ある、 $\mathrm{A}_{i}$ からその潾の 8 面体位置 $\mathrm{B}_{i}$ への水素の移行速度 は，(1) $A_{i}$ に和ける水素の振動数，(2) $A_{i}$ 火打汗る水素濃 度，(3) $A_{i}$ と $B_{i}$ の間の鞍点のポテンシャルエネルギーと $\mathrm{A}_{i}$ のポテンシャルエネルギーとの差によって決变り，各

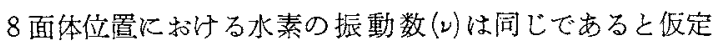
する．Fig.5 の図中に示したよらに，aだけ離れた面A と 面 $\mathrm{B}$ の距離座標をそれぞれ $x, x+a$ と乱けば， $\mathrm{A}_{1}$ から $\mathrm{B}_{1}$ への水素の移行速度は $\nu C_{\mathrm{t}}(x) \exp \left\{-\left(E_{\mathrm{B} 1}+Q-\Delta E\right) /\right.$ $R T\}, B_{1}$ から $\mathrm{A}_{1}$ への移行速度は $\nu C_{0}(x+a) \exp \{-(Q-\Delta E) /$ $R T\}$ となる。同様に， $\mathrm{A}_{2} \rightarrow \mathrm{B}_{2} ; \nu C_{0}(x) \exp \{-(Q-\Delta E) /$ $R T\}, \mathrm{B}_{2} \rightarrow \mathrm{A}_{2} ; \nu C_{t}(x+a) \exp \left\{-\left(E_{\mathrm{B} 1}+Q-\Delta E\right) / R T\right\}, \mathrm{A}_{3}$ $\rightarrow \mathrm{B}_{3} ; \nu C_{0}(x) \exp (-Q / R T), \mathrm{B}_{3} \rightarrow \mathrm{A}_{3} ; \nu C_{0}(x+a) \exp (-Q)$ $R T)$ となる，前述の搪散経路の存在確率を考慮す机は，面 Aから面 $\mathrm{B}$ ○乐素の流れJは次式で表方される。

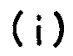

(ii)
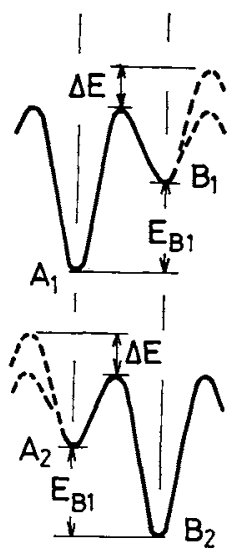

(iii)
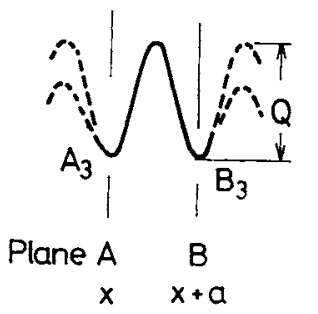

Fig.5 Potential energy of the diffusing hydrogen atom : (i) and (ii); diffusion path of the hydrozen atom affected by a substitutional alloying element, (iii); diffusion path in normal lattice sites.

$$
\begin{aligned}
J= & \nu a \exp (-Q / R T)\left\{1-2 K_{1}+2 K_{1} \exp (\Delta E / R T)\right\} \\
& \cdot\left\{C_{0}(x)-C_{0}(x+a)\right\}
\end{aligned}
$$

$J=-D(\mathrm{~d} C / \mathrm{d} x), D_{0}=\nu a^{2}$ と和忊ば，式 (3)，(4)から水素 の昖散保数に対する合金元素の影響をつぎのように表わす ことができる。

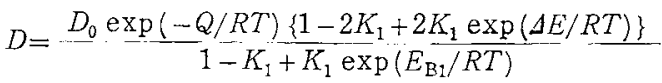

式(5)の $D_{0}, Q$ の值は，合金元素や転位などのトラッ プの影響を受けていない鉄中の水素の抎散係数の温度依存 性から求めることができる。すなわち，

$$
\begin{aligned}
D_{0} & =1.1 \times 10^{-7} \mathrm{~m}^{2} / \mathrm{s}^{(29)} \\
Q & =6700 \mathrm{~J} / \mathrm{mol}^{(29)}
\end{aligned}
$$

また合金トラップの密度 $K_{1}$ と合金量 $C_{\mathrm{x}}(a t \%)$ との関係 は次式で表わされる。

$$
C_{\mathrm{x}}=50 K_{1}
$$

一方 Koiwa(37) も本研究と同様炕, Fig.4のポテンシャ ルモデルに基づいて㯰換型合金元素のトラップ効果を論し ている，彼は確率過程論に掂ける平均初回通過時間の理諭 を用いて，固溶水素量が極めて少ない場合について，トラ ップ位置の水素と格子間位置の水素々の間の平衡を仮定す ることなく，合金鋼中の水素の拡散係数を表わす理論式を 導き，式(5) と異なる結果を得ている。しかし拡散係数の 実測值を式(5)范るいは Koiwa の式のどららで考察する かてついては，その測定法が問題となる。

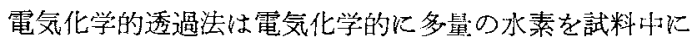
導入して，その透過速度の時間変化を測定するものであっ て, 透過曲線は非平衡状態の水素の拡散, 透過をあらわし ている、すなわち水素の透過曲線の測定においては，各安 定位置の水素の濃度 (存在確率) 時間の増加とともに固溶水素量が堌加して，固溶水素の分 布は非平衡状態から平衡状態へ近らくよらに变化する。る

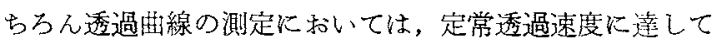
も平衡状態ではないが，その際の各安定位置に叔ける水素 の濃度は局部平衡を保つものとみなされよら。つまり陚料 をカソード分極した直後のように固溶水素量が少なくて非 平衡状態にある水素の拊散係数は，Koiwa の理論式で表 わされるのに対して，透過速度が定常状態達すると，そ

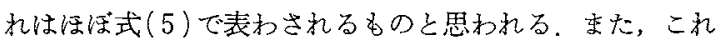
らの理論式，すなわち Koiwa の式と著者らの式（5)によ る拡散係数の計算值が，Fig.4のポテンシャルモデルに拉 いて $\Delta E \neq 0$ の場合には異なることから，カソード分極直 後と定常透過速度に爑した場合とでは，一般には昖散保数 の測定值が変化することが予想される，ところが電気化学 的透過法尤上って実験的煌られる水素の透過明線の形 は,トラップの効果ばかりでなく，カソ一ド電流密度，陚 料の板厚などの実験条件によっても複雑に変化するる めに，水素吸収時間に上って拡散保数の值が変化する場合 には，抬散係数の亚確な值を求めることができない，した がって本実験に扔いては，(i)水素の拡散係数は固溶水素 
量に依存しない，(ii) 固溶水素の分布は局部平衡の条件を 満足することを仮定して透過曲線を解析し，透過曲線の測 定中における平均的な拡散係数の值を求めた。このような 解析法沉基づいて得られる払散係数の值について考察する 場合には，理諭式を導く祭の仮定から判断して，上述の Koiwa式よりも式(5)を用いる方がむしろ有効ではない かと思われる。

以上の上うに本研究のトラップモデルに叔いては，固溶 水素の分们化平衡を仮定し，すべての水素の隣接 8 面体位 置への移行速度を平均すること炕よって合金鋼中の水素の 桩散保数を求めるために，当然式(5)の有效性には限界が 存在する。また前述のようにして得られる水素の拡散俰数 の実測檤も粗い仮定に基づくものではあるが，室温付近に お壮る合金鋼中の水素の払散係数を，固溶水素量や固溶水 素の分布々対苮さ好て正確飞測定する方法が確立していな い垷在，水素の抬散係数におよぼす合金元素の影響の忩ら 李しを明らかにするために，一応式(5)を用いて拡散係数 の央測值を考察する。

\section{2. $270 \sim 300 \mathrm{~K}$ での $\boldsymbol{\alpha}$ 鉄中の水素の拡散係数}

これまで報告されている室温付近での， $\mathrm{Fe}-\mathrm{Ni}(13)(16)$ ${ }^{(18)}, \mathrm{Fe}-\mathrm{Cr}$ 合金 ${ }^{(13)(15)(19)}$ 中の水素の拡散俰数の測定值を Fig.6，7亿示す。これからわかるよ5に， $\alpha$ 相領域に打 ける測定值は少なく，しかもばらつきが大きい，また $\mathrm{Fe}$ Co 合金に関しての報告は見当たらない。このように比較

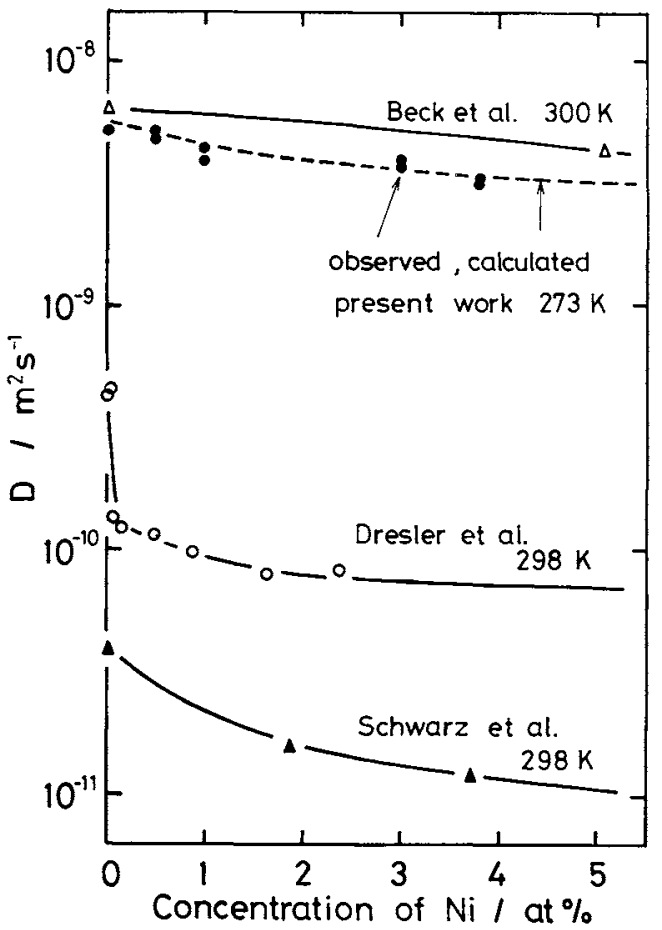

Fig.6 Diffusion coefficient as a function of the $\mathrm{Ni}$ concentration. Dashed curve is calculated from eq. (10); $\Delta E=4.2 \mathrm{~kJ} / \mathrm{mol}$ and $E_{\mathrm{B} 1}=7.6 \mathrm{~kJ} / \mathrm{mol}$.
すべき測定結果に乏しいが，本研究に沏ける測定結果は $\mathrm{Fe}-\mathrm{Ni}$ 合金で蛙 Beck らの結果 ${ }^{(16)}$ K， Fe-Cr 合金では 中井の結果 ${ }^{(19)}$ そ泳ぼ一致している。転位などの格子欠陷 の影響を受けていない純鉄中の水素の拡散係数は $298 \mathrm{~K}$ K

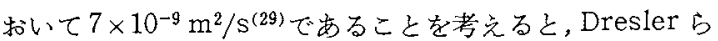
(17), Bockris $ら^{(15)}$, Schwarz ら ${ }^{(13)}$ の結果はいずれもか なり小さくてっこれらの測定結果は合金元素の他に転位な どの格子欠陷の影響を受けていることが想像される。

Figs.1〜3には，前報 ${ }^{299}$ で報告した格子欠陷の影響を 受けていない鉄中の水素の桩散係数 $\left(D_{1}\right)$ と，電解鉄(多結 晶)中の水素の桩散係数の実澌值（図中の・印）を示した. これから明らかなように，270〜300 K の温度範团では， 電解鉄中の水素の抁散保数の実测值は $D_{1}$ の值に泳ぼ一致 するが，低温になると格子欠陥の影響を強く受けて， $D_{1}$ の値よりもかなり小さくなる。本実験に用いた合金試 料中の水素の拡散保数に対してる，270～ $300 \mathrm{~K}$ の範团で は合金元素以外の格子欠陷のトラップ効果を無視できるも のをすれば，本実験で測定したこの温度範国での $\alpha$ 鉄中 の水素の昖散係数の合金量依存性は，合金元素のみのトラ

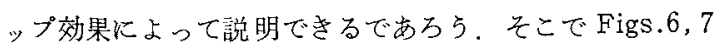

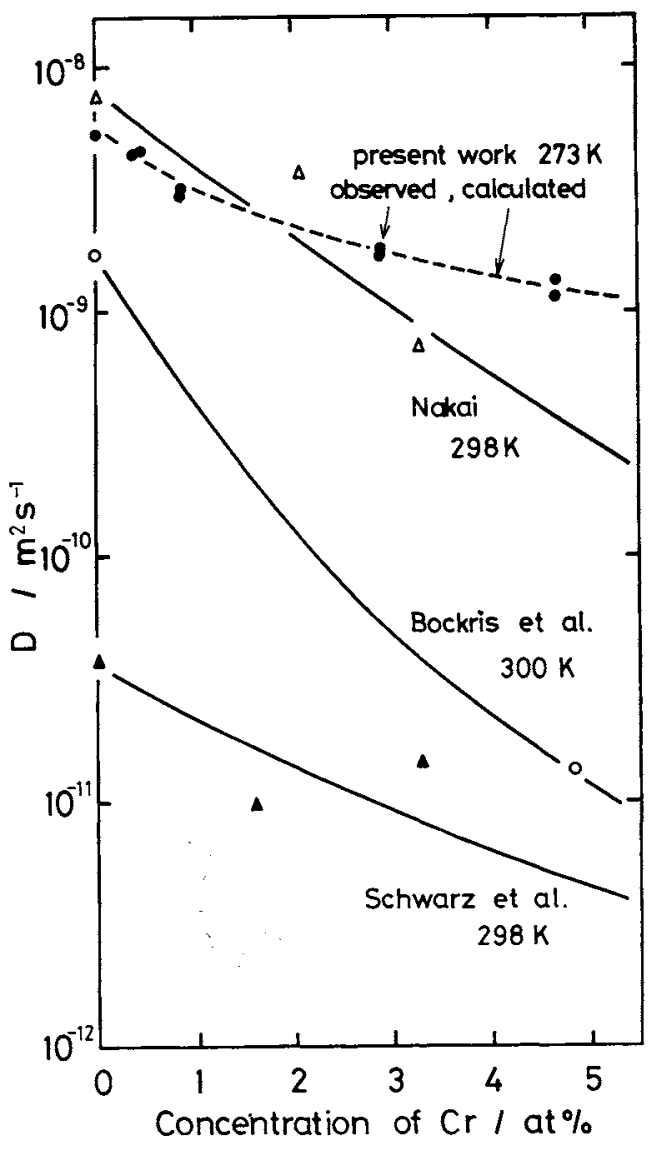

Fig.7 Diffusion coefficient as a function of the $\mathrm{Cr}$ concentration. Dashed curve is calculated from eq. $(10) ; \Delta E=0$ and $E_{\mathrm{B} 1}=8.4 \mathrm{~kJ} / \mathrm{mol}$. 
に示した本実験での $273 \mathrm{~K} に お け る$ 测定值を，合金元素 のみのトラップ効果を定式化した式(5)を用いて考察す る:

式( 5 )による理論値と測定值とが比較的よく一致するよ $5 \kappa, \Delta E$ と $E_{\mathrm{B} 1}$ の值を沠めて求め大理論曲線もFigs.6. 7 飞示す。ここで $\mathrm{Fe}-\mathrm{Cr}$ 合金の場合には, $\Delta E=0, E_{\mathrm{B} 1}=$ $8.4 \mathrm{~kJ} / \mathrm{mol}$ で西り, $\mathrm{Fe}-\mathrm{Ni}$ 合金の場合には, $\Delta E=4.2 \mathrm{~kJ} /$ $\mathrm{mol}, E_{\mathrm{B} 1}=7.6 \mathrm{~kJ} / \mathrm{mol}$ である。前述のように仮定する トラップモデルが極めて単縌であることと，式(5)の $\Delta E$ ， $E_{\mathrm{B} 1}$ を評価できないことなどから，測定結果に関する詳細 な検討は困難である。しかし測定值と理諭曲線との変化の 傾向は活ぼ一致して拈り，273 K に拈ける水素の拡散係数 の合金量低存性は式（5）で忹活説明できるよう火思われ る.

\section{3. $\boldsymbol{\alpha}$ 鉄中の水素の拡散係数の温度依存性}

前述の上うに270 300 Kに护ける電解鉄中の水素の拡 散係数に対する格子久陷の影響は大きくないが，270 K 以 下では格子欠宿のトラップ効果を無視できない(29)。この 詳細な原因はわからないが，電解鉄见括ける水素の拡散係 数の温度伐存性は，主として転位のトラップ効果の影響を

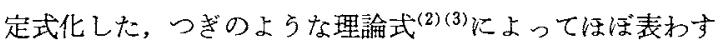
ことができる(29).

$$
D=\frac{D_{0} \exp (-Q / R T)}{1-\bar{K}_{2}+K_{2} \exp \left(E_{\mathrm{B} 2} / R T\right)}
$$

式(9)中の $E_{\mathrm{B} 2}$ 快水素々格子久陌(転位)の相互作用工亦 ルギー， $K_{2}$ は 8 面体位置の総数化対する $E_{\mathrm{B} 2}$ の相互作用 エネルギーを持つトラップ位置の数の割合である． $E_{\mathrm{B} 2}$ の 值としては，転位と水素の相互作用エネルギーとして，こ れまで報告されている測定値 $\left(26 \mathrm{~kJ} / \mathrm{mol}^{(2)}\right)$ 仮定し， 式 (9)による理論值と電解鉄における実測值とが注に゙ー致 するよらに $K_{2}$ の値を决めると， $K_{2}=1 \times 10^{-6}$ となる(29).

式 (9)索導く際に用いたポテンシャルモデルは，水素々 $E_{\mathrm{B} 2}$ の相互作用エネルギーを持つトラップ位置としての転 位が金属中に均一に分布していると考穴たものである。し たがって転位のトラップ効果を議論するモデルとしては， かなり粗い仮定に基づくものである。しかし前述のよらに $E_{\mathrm{B} 2}$ と $K_{2}$ の值を適当に仮定すれば，電解鉄中の水素の拡 散係数の実測值(温度依存性)を注ぼ式(9)によって説明で きることから判断すると，電解鉄中の水素の搪散係数に対 する格子久宿のトラップ効果の精密忹論は困難として もそそのあらしについてはこのようなポテンシャルモデ ルで近似できるように思われる。

もし合金 $\mathrm{Fe}-\mathrm{X}$ 中に，転位のような格子欠陥がトラッ プ位置として, 前述の合金トラップ位置とは独立に存在し ており，前述の $E_{\mathrm{B} 2} ， K_{2}$ の值が仮りに電解鉄中のそれぞれ の值と同じであるとすれば，合金銅中の水素の拡散保数は 㴗济次式で与完られるはずである：
$D=\frac{D_{0} \exp (-Q / R T)\left\{1-2 K_{1}+2 K_{1} \exp (\Delta E / R T)\right\}}{1-K_{1}-K_{2}+K_{1} \exp \left(E_{\mathrm{B} 1} / R T\right)+K_{2} \exp \left(E_{\mathrm{B} 2} / R T\right)}$

ここで, $E_{\mathrm{B} 2}=26 \mathrm{~kJ} / \mathrm{mol}^{(2)}, K_{2}=1 \times 10^{-6(29)}$ である. 式 (10) 飞適当な $\Delta E$ と $E_{\mathrm{B} 1}$ の值を代入して得られる理論朋 線をFigs.1〜3 中に示した。この場合に低温になる汪ど $E_{\mathrm{B} 2}$ の相互作用エネルギーを持つトラップ位置(格子欠陷) の影響が大きくなるのでななるべくその影暗が少ない温度 笧囲，つまり電解鉄での測定値に执いて，格子欠宿の影響 がほぽ無視できる温度範囲 $(270 〜 300 \mathrm{~K})$ に括ける実測值と 理論值とが比較的一致するように， $A E$ と $E_{\mathrm{B} 1}$ の値を決め

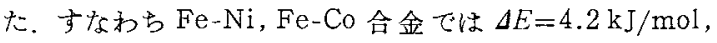
$E_{\mathrm{B} 1}=7.6 \mathrm{~kJ} / \mathrm{mol}, \mathrm{Fe}-\mathrm{Cr}$ 合金では $\Delta E=0, E_{\mathrm{B} 1}=8.4 \mathrm{~kJ} /$ $\mathrm{mol}$ となるが，実測值と理論值とは必ずしも一致しないの で， $\Delta E$ と $E_{\mathrm{B} 1}$ の値にはかなりの幅がある。このように， 純鉙中に $\mathrm{Ni}, \mathrm{Co}$ を添加すると，合金元素の最隣接 4 面体 位置と最鲜接 8 面体位置化括汀る水素のポテンシャルエネ ルギーは，それぞれ $\Delta E=4.2 \mathrm{~kJ} / \mathrm{mol} ， E_{\mathrm{B} 1}=7.6 \mathrm{~kJ} / \mathrm{mol}$ 程度低下するよらに思われる。また $\mathrm{Fe}-\mathrm{Cr}$ 合金では $\Delta E$ $\simeq 0$ であるが， $E_{\mathrm{B} 1}$ の值は約 $8.4 \mathrm{~kJ} / \mathrm{mol}$ であって, $\mathrm{Fe}$ $\mathrm{Ni}, \mathrm{Fe}-\mathrm{Co}$ 合金に比較してやや大きい上らに思われる。

$\alpha$ 銠中の水素の桩散に対する合金元素の影響について, 合金元素によるトラップ効果の側面から考察して, その相 互作用エネルギーを求めた。しかしトラップ効果の詳細な 機構についてはな和不明であって，水素之置換型溶質原子 との相互作用を評価するにはなな打精密な理論と実験との 集積が必要であると思われる。

\section{V. 結 論}

置換型合金元素 $\mathrm{Ni}, \mathrm{Cr} ， \mathrm{Co}$ を添加した $\alpha$ 鉄中の水素の 拡散保数を $230 \sim 300 \mathrm{~K}$ に拉いて電気化学的透過法で求め た．さらに水素の拡散保数に対する合金元素の影響をトラ ップモデルを用いて定式化した。こうして得られた搪散係 数敒関する計算結果と実験結果とを比較して,つぎの結論 を得た。

(1) 電解鉄に上記の合金元素を添加すると拡散係数は減 少する，Ni，Cok比べてCrを合金した場合が最も㧓散 俰数は小さくなる。

(2) 置換型合金元素を添加したことによって，最隣接 4 面体位置と最隣接 8 面体位置の水素のポテンシャルエネル ギーがそれぞれ $\Delta E ， E_{\mathrm{B} 1}$ だ沙減少することと，水素の分布 が熱平衡の条件で与えられることを仮定すれば，抁散係数 (D)は次式で表わされる。

$$
D=\frac{D_{0} \exp (-Q / R T)\left\{1-2 K_{1}+2 K_{1} \exp (\Delta E / R T)\right\}}{1-K_{1}+K_{1} \exp \left(E_{\mathrm{B} 1} / R T\right)}
$$

（3）実测された合金鋼中の $D$ の温度依存性を説明する ためには，合金元素のトラップ効果の他に格子久宿の影響 を考慮しなくてはならない. 合金元素と格子欠楩の 2 種類 のトラップの影響を受ける場合の $D$ の温度依存性を, ト 
ラップモデルを用いて定式化して，実測值と比較した。 $\mathrm{Fe}-\mathrm{Cr}$ 合金の $D$ の温度依存性の害測結果は $\Delta E=0, E_{\mathrm{B1}}=$ $8.4 \mathrm{~kJ} / \mathrm{mol}$ とすることにより，末た Fe-Ni，Fe-Co 合金 の場合には $J E=4.2 \mathrm{~kJ} / \mathrm{mol}, E_{\mathrm{B} 1}=7.6 \mathrm{~kJ} / \mathrm{mol}$ とするこ とによってほぼ説明できる。

最後に，本矿究を行ならにあたって実釦に協力された九 州大学工学部治金学科学生 占賀一弘殴(現在 : 大和製罐株 式会社)，鉄鋼治金学科学生 日高芳博氏(垷在：宫崎访役 所)に深く謝意を表する。

\section{文軦}

(1) J.Völk1 and G.Alefeld : Diffusion in Solids, Ed.by A.S.Nowick and J.J.Burton, Academic Press, N.Y.,(1975), 231.

（2）浅野 滋，原 和久，中持揚一，大谷南海男：日本 金属学会誌, 38(1974)，626。

（3）中井攅一：水素儿よる遅れ破壊の機構，鉄鈯基礎共 同研究会, (1975)，75.

(4) W.Beck, J.O'M.Bockris, J.McBreen and L. Nanis : Proc. Roy. Soc., A $290(1966), 220$.

(5) B.Chew and F.T.Fabling : Met.Sci.J.,6(1972), 140.

(8) G. Vibrans : Arch. Eisenhüttenw., 32(1961), 667.

(7) G.Lange and W.Hofmann: Arch. Eisenhüttenw., $37(1966), 391$.

(8) G.M.Evans and E.C.Rollason : J.Iron Steel Inst., 207 (1969), 1591.

(9) M.R.Louthan, A.H.Dexter and J.A. Donovan: J.Iron Steel Inst., $210(1972), 57$.

(10) H.G.Ellerbrock, G.Vibrans and H.P.Stüwe : Acta Met., 20(1972), 53

(11) D.M.Allen-Booth and J.Hewitt : Acta Met., 22 (1974) , 171.

(12) W.Geller and Tak-Ho Sun : Arch. Eisenhüttenw., 21 (1950), 423.

(13) W.Schwarz and H. Zitter : Arch. Eisenhüttenw., 36(1965), 343.

(14) J.F.Newman and L.L.Shreir : J.Iron Steel Inst., $207(1969), 1369$.
(15) J. O'M. Bockris, M. A. Genshaw and M. Fullenwider : Electrochimica Acta, 15(1970), 47.

(16) W.Beck, J.O'M.Bockris, M.A.Genshaw and P.K.Subramanyan : Met. Trans., 2(1971), 883.

(17) W.Dresler, M.G.Frohberg and H.G.Feller : Z. Metallkde., $63(1972), 94$.

(18) W.Dresler and M.G.Frohberg : J.Iron Steel Inst., $211(1973), 298$.

（19）中乎掦一，上杉康治，沜中浩：川崎製鉄技報，6 (1974), 324.

(20) L.S.Darken and R.P.Smith : Corrosion, 5 (1949), 1.

(21) H. Schumann and F. Erdmann-Jesnitzer : Arch. Eisenhüttenw., 24 (1953), 353.

(22) M.L.Hill and E.W.Johnson: Trans.Met.Soc. AIME, $215(1959), 717$.

(23) J.Y.Choi : Met. Trans., 1(1970), 911.

(24) J. O'M. Bockris and P. K. Subramanyan : J. Electrochem. Soc., $118(1971), 1114$.

(25) M.A.V.Devanathan and Z.Stachurski : Proc. Roy. Soc., A 270(1962), 90.

(20) J.McBreen, L.Nanis and W.Beck : J.Electrochem. Soc., $113(1966), 1218$.

(27) 浅野 滋, 藤嶋等婎, 大谷南海男：日本金属学会 誌, $37(1973), 301$.

(28) W.Raczynski and S.Stelmach : Bull. Acad. Polon. Sci., Ser. Sci. Chim., 9(1961), 633.

(29) 羽木秀樹, 林 安衡, 大谷南海男：日本金属学会 誌, 42(1978), 801 .

H.Hagi, Y.Hayashi and N.Ohtani : Trans. JIM, 20 (1979), 349.

(30) M. Hansen : Constitution of Binary Alloys, McGraw Hill, N.Y.,(1958), p.472, 527, 678.

(31) A.McNabb and P.K.Foster: Trans. Met.Soc. AIME, $227(1933), 618$.

(32) H.Gaus : Z.Naturf., 20 a (1965), 1298.

(33) G.R.Caskey and W.L.Pillinger : Met. Trans., 6A (1975), 467 .

(34) B.Chew : Met. Sci, Eng., 5(1971), 195.

(35) D. M. Allen-Booth, C. Atkinson and B. A. Bildy : Acta Met., 23 (1975), 371.

(36) R.A.Oriani : Acta Met., 18(1970), 147.

(37) M.Koiwa : Acta Met., 22(1974), 1259.

(38) M. A. Krivoglatz and A. A. Smirnov : The Theory of Order-Disorder in Alloys, MacDonald, (1964), p.236. 